\title{
Abundance, oxygen consumption and carbon demand of brittle stars in Young Sound and the NE Greenland shelf
}

\author{
Martin Emil Blicher ${ }^{1,2, *}$, Mikael Kristian Sejr ${ }^{2}$ \\ ${ }^{1}$ Greenland Climate Research Centre, Greenland Institute of Natural Resources, Kivioq 2, Box 570, 3900 Nuuk, Greenland \\ ${ }^{2}$ National Environmental Research Institute, Aarhus University Vejlsøvej 25, 8600 Silkeborg, Denmark
}

\begin{abstract}
We used sea floor photography to estimate brittle star abundance in Young Sound, NE Greenland and the adjacent shelf. From photos covering a total area of $78 \mathrm{~m}^{2}$ and spanning a depth range from 20 to $310 \mathrm{~m}$ we found maximum average densities of $>400$ ind. $\mathrm{m}^{-2}$ at 40 to $80 \mathrm{~m}$ depth. Ophiocten sericeum was the dominant species. However, gradual changes in species and size composition with depth were observed. Average biomass was $\sim 600 \mathrm{mg} \mathrm{C} \mathrm{m}^{-2}$ with highest values at sites dominated by the large Ophiopleura borealis (up to $2190 \mathrm{mg} \mathrm{C} \mathrm{m}^{-2}$ ). We measured average individual oxygen consumption of 3 dominant species at ambient temperature $\left(-1.0^{\circ} \mathrm{C}\right)$ and salinity in incubation chambers using a fiber-optic oxygen sensor enabling continuous measurements. We established a general relation between individual disc diameter $(D, \mathrm{~mm})$ and oxygen consumption $(R$, umol O $\mathrm{h}^{-1}$ ind. $\left.^{-1}\right): R=6.0 \times 10^{-4} \times D^{2.60}\left(\mathrm{R}^{2}=0.96, \mathrm{n}=33\right)$, which facilitated the estimation of community respiration and carbon demand from sea floor images. Peaks in total carbon demand were found in the fjord at $\left.30 \mathrm{~m} \mathrm{(14} \mathrm{mg} \mathrm{C} \mathrm{m}{ }^{-2} \mathrm{~d}^{-1}\right)$ and $160 \mathrm{~m}$ depth $\left(13 \mathrm{mg} \mathrm{C} \mathrm{m}^{-2} \mathrm{~d}^{-1}\right)$, resulting from high densities of medium sized (10 to $15 \mathrm{~mm}$ disc diameter) $O$. sericeum, and the presence of the very large (20 to $35 \mathrm{~mm}$ disc diameter) $O$. borealis, respectively. At the other stations values ranged from 0.5 to $8 \mathrm{mg} \mathrm{C} \mathrm{m}^{-2} \mathrm{~d}^{-1}$. Overall, our results demonstrate that brittle stars, despite very low individual energy requirements, contribute significantly to marine carbon cycling in Young Sound as well as in the shelf areas off NE Greenland.
\end{abstract}

KEY WORDS: Arctic $\cdot$ Macrobenthos $\cdot$ Epifauna $\cdot$ Respiration $\cdot$ Sea floor photography $\cdot$ Megafauna Benthos

Resale or republication not permitted without written consent of the publisher

\section{INTRODUCTION}

Brittle stars (Echinodermata; Ophiuroidea) form dense assemblages in several marine habitats and in the deep sea around the world (e.g. Tyler 1980, Smith 1983, Brey \& Clarke 1993, Quiroga \& Sellanes 2009). Despite their widespread occurrence in coastal areas in the Arctic (Piepenburg 2000) few studies have focused on the ecology of brittle stars and therefore little is known about the significance of brittle stars in ecosystem carbon cycling. Respiration is a very fundamental parameter that can be used to estimate the population energy demand and importance in ecosystem carbon cycling. To our knowledge, only 3 studies have estimated respiration rates of Arctic brittle stars.
In the Beaufort Sea, Renaud et al. (2007) measured oxygen consumption of several dominant species, including several species of brittle stars, but specific oxygen consumptions rates for brittle stars were not presented. In the Chukchi Sea, Ambrose et al. (2001) estimated oxygen consumption of Ophiura sarsi with a mean disc diameter of $2.2 \mathrm{~cm}$ with and without the addition of algae, but relied on a general relation between mass-specific respiration and biomass (Mahaut et al. 1995) to calculate population respiration due to uncertainties as to the reliability of their measurements. The most detailed study was performed by Schmid (1996), who estimated oxygen consumption of 33 specimens belonging to 4 different species within a relatively narrow size interval. 
In Young Sound, NE Greenland, brittle stars have been registered as a dominant epifaunal group at shallow depths $(<60 \mathrm{~m})$ with densities up to several hundred individuals per square meter (Sejr et al. 2000). In this study, we complement previous studies by estimating abundance of brittle stars in the deeper part of the fjord and along a transect into the Greenland Sea. We then measure oxygen consumption of the dominant species and produce an estimate of the daily carbon demand by brittle stars in the study area.

\section{MATERIALS AND METHODS}

Study area. The study was conducted in the outer part of Young Sound ( $\left.74^{\circ} 18^{\prime} \mathrm{N}, 20^{\circ} 15^{\prime} \mathrm{W}\right)$ and outside the fjord entrance on the continental shelf in the Greenland Sea, NE Greenland, in August 2009. Young Sound is a $90 \mathrm{~km}$ long and 2 to $7 \mathrm{~km}$ wide sill fjord, with a mean depth of $100 \mathrm{~m}$. The fjord is ice-covered from October/November to July and water temperatures never exceed $-1.0^{\circ} \mathrm{C}$ below the subsurface layer (>20 m) (Bendtsen et al. 2007). Phytoplankton production is confined to the ice-free period, and characterised by a peak subsequent to the break-up of sea ice, usually lasting a few weeks until nutrients are depleted in the surface layer.

Abundance, biomass and size frequency. A series of high-resolution digital photos (Ocean Imaging Systems) of the sea floor were taken along 3 depth-transects in Young Sound at 20, 30, 40, 50, 60, 80, 100 and $160 \mathrm{~m}$ depth, and at 4 stations on the Greenland Sea shelf ranging in depth from 200 to $310 \mathrm{~m}$. Ten photos from each station (26 stations in total, each photo covering $0.3 \mathrm{~m}^{2}$ ) were used to quantify the abundance of brittle stars. Using the image processing software ImageJ 1.43r, we measured the disc diameter of brittle stars in the photos in order to describe the size frequency distribution. Biomass was estimated on the basis of the allometric relationship between disc diameter, $D(\mathrm{~mm})$ and individual body mass, $M(\mathrm{mg}$ organic C) for Ophiocten sericeum in the Barents Sea: $M=$ $0.016 \times D^{2.622}$. The relationship for Ophiura sarsi: $M=$ $0.019 \times D^{2.796}$ was used to convert disc diameter to biomass for Ophiopleura borealis (Piepenburg 2000).

Oxygen consumption. Brittle stars were collected with a small dredge at 20,60 and $160 \mathrm{~m}$ depth in Young Sound. Specimens were transferred to an aquarium containing bottom water and returned quickly to the laboratory, where they were carefully sorted with respect to species and size. After an immediate escape response due to handling, brittle stars quickly returned to a normal, rather slow-moving, activity pattern. To allow recovery from handling, they were held in open incubation chambers in aerated sea- water at ambient temperature $\left(-1.0^{\circ} \mathrm{C}\right)$ and salinity for $\sim 1 \mathrm{~h}$ before metabolic measurements were initiated. Due to the relatively short recovery periods specimens were assumed to have been actively feeding until shortly before the beginning of our measurements. We measured oxygen consumption, $R\left(\mu \mathrm{mol} \mathrm{O}_{2} \mathrm{~h}^{-1}\right.$ ), of Ophiocten sericeum, Ophiura robusta and Ophiopleura borealis in closed incubation chambers kept in the dark, using a fiber-optic oxygen sensor (FIBOX, PreSens) and oxygen-sensitive optode patches calibrated to zero oxygen (sodium dithionite solution) and air saturated water. This system enabled continuous measurements of oxygen concentration in the closed chambers. Chamber volumes ranged from 240 to $360 \mathrm{ml}$. The water was stirred by a $20 \mathrm{~mm}$ Tefloncoated magnet $(60 \mathrm{rpm})$ fixed at the centre of the chambers. To reduce incubation times (average of the experiments was $\sim 4 \mathrm{~h}$ ), we measured total oxygen consumption of batches of 4 to 13 individuals of similar disc diameter $(\sim 1 \mathrm{~mm})$, corresponding to previous observations of brittle star densities in the Arctic (Piepenburg 2000, Sejr et al. 2009). Thus, we obtained an average estimate of individual $R$ (corrected for a control without brittle stars). For the large $O$. borealis, only one specimen was included in each incubation chamber.

Carbon demand. Total oxygen consumption of the brittle star community, $R_{\text {total }}$, was calculated by a combination of (1) the size frequency, (2) the abundance (ind. $\mathrm{m}^{-2}$ ), and (3) the relation between disc diameter and individual oxygen consumption:

$$
R_{\text {total }}=\sum N_{i} \times R_{i}
$$

where $N_{i}$ and $R_{i}$ are the number of brittle stars and the average individual oxygen consumption, respectively, in size class $i$ ( $1 \mathrm{~mm}$ intervals). Thus, an average $R_{\text {total }}$ was estimated for each station.

Oxygen consumption was converted to carbon mineralisation by assuming a respiratory coefficient, $R Q$, of 0.7 (Grebmeier et al. 2006). An assimilation efficiency of 0.8 and a net growth efficiency of 0.3 (e.g. Navarro \& Thompson 1996, Sejr et al. 2004) result in $56 \%$ of the ingested carbon being mineralised. Thus, estimates of carbon requirements could be obtained by multiplying the respiration-derived mineralisation rates by a factor of 1.79 .

\section{RESULTS}

\section{Abundance and biomass}

Peak abundance of brittle stars was found at 40 to $80 \mathrm{~m}$ depth in Young Sound (Fig. 1a) with an average abundance of at least 200 ind. $\mathrm{m}^{-2}$. Maxi- 
mum abundance was 445 ind. $\mathrm{m}^{-2}$ at $60 \mathrm{~m}$. At depths $<100 \mathrm{~m}$ Ophiocten sericeum prevailed. Ophiura robusta was occasionally found at 30 to $60 \mathrm{~m}$ in the fjord but never constituted more than 1 to $2 \%$ of total abundance. At 2 stations (100 and $160 \mathrm{~m}$ ) only the very large Ophiopleura borealis was observed. On the shelf, abundance decreased steadily with depth, from 162 ind. $\mathrm{m}^{-2}$ at $200 \mathrm{~m}$ to 9 ind. $\mathrm{m}^{-2}$ at $310 \mathrm{~m}$, coinciding with a change in dominance from $O$. sericeum to Ophiacantha bidentata and $O$. borealis. Maximum biomass (average $2190 \mathrm{mg} \mathrm{C} \mathrm{m}^{-2}$ ) was found at $160 \mathrm{~m}$ in Young Sound due to the dominance of the very large species O. borealis (Fig. 1b). High biomass was also found at $30 \mathrm{~m}$ (1088 $\mathrm{mg} \mathrm{C} \mathrm{m} \mathrm{m}^{-2}$ ) due to high abundance of relatively large $O$. sericeum. Lowest biomass was found at the deepest station in the Greenland Sea (36 $\mathrm{mg} \mathrm{C} \mathrm{m}^{-2}$ ).

\section{Size frequency}

The size distribution of the dominant species, Ophiocten sericeum, changed with depth. Median $D$ in Young Sound ranged from $10.3 \mathrm{~mm}$ at 20 to $30 \mathrm{~m}$ depth to $5.0 \mathrm{~mm}$ at 40 to $80 \mathrm{~m}$ (Fig. 2a) and was $9.9 \mathrm{~mm}$ at 100 to $160 \mathrm{~m}$. Median $D$ in the Greenland Sea was $6.9 \mathrm{~mm}$ at 200 to $310 \mathrm{~m}$ depth. The occurrence of Ophiopleura borealis is seen in the bi-modal distribution of size frequencies (Fig. 2b) at the 100 to $160 \mathrm{~m}$ depth interval. The median $D$ of $O$. borealis was $27.6 \mathrm{~mm}$.

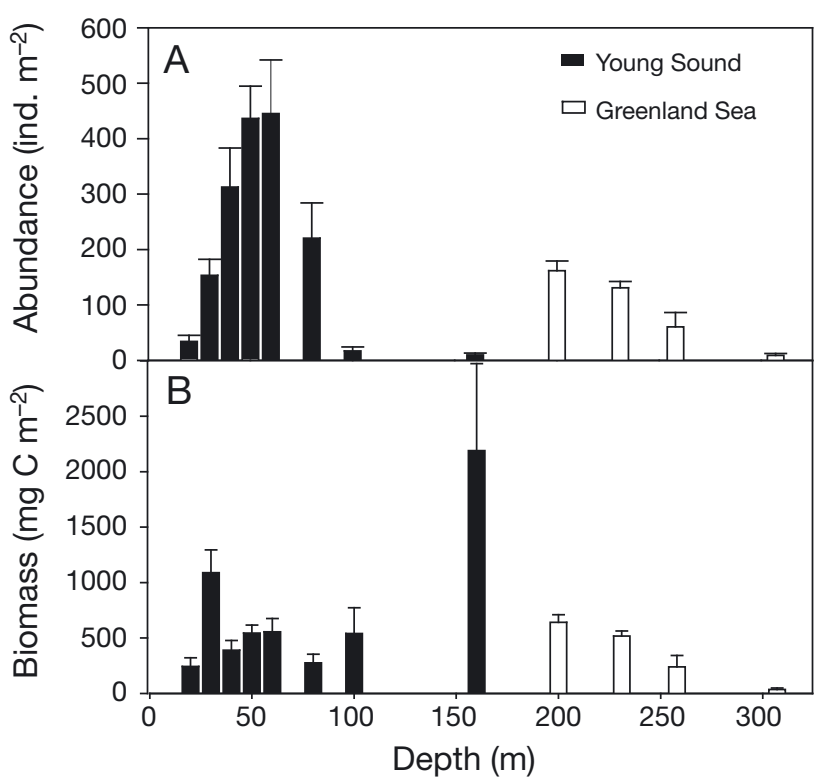

Fig. 1. (A) Average abundance $( \pm 95 \%$ CI) of brittle stars in Young Sound and the Greenland Sea obtained from sea floor photography, and (B) estimated biomass (average $\pm 95 \% \mathrm{CI}$ )

\section{Oxygen consumption}

We measured oxygen consumption $\left(R, \mu \mathrm{mol} \mathrm{O} \mathrm{O}^{-1}\right.$ ind. ${ }^{-1}$ ) of 33 batches of brittle stars (226 specimens in total). In all cases we observed a linear decrease in $\mathrm{O}_{2}$ concentration in the incubation chambers $\left(R^{2}>0.95\right)$. The average individual oxygen consumption rate ranged from $0.04 \mu \mathrm{mol}$ ind. ${ }^{-1} \mathrm{~h}^{-1}$ in Ophiocten sericeum with an average disc diameter of $5.0 \mathrm{~mm}$ (13 ind. in chamber) to $4.7 \mu \mathrm{mol}$ ind. ${ }^{-1} \mathrm{~h}^{-1}$ for Ophiopleura borealis with a disc diameter of $29.6 \mathrm{~mm}$ (Fig. 3a). In the 3 species investigated, no apparent difference in the relationship between consumption rate and size were observed. Hence, $R$ increased allometrically with increasing $D$ across species according to: $R=6.0 \times 10^{-4} \times D^{2.60}\left(\mathrm{R}^{2}=\right.$ $0.96, \mathrm{n}=33$ ).

\section{Carbon demand}

Maximum carbon demand was found in the fjord at

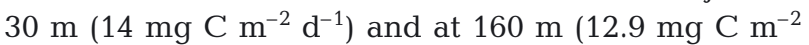
$\left.\mathrm{d}^{-1}\right)$. At the remaining stations, values ranged from 3 to $8 \mathrm{mg} \mathrm{C} \mathrm{m}^{-2} \mathrm{~d}^{-1}$ except at the deepest station $(310 \mathrm{~m})$ where carbon demand was $0.5 \mathrm{mg} \mathrm{C} \mathrm{m}^{-2} \mathrm{~d}^{-1}$ (Fig. 4).

\section{DISCUSSION}

The estimated carbon demand for brittle stars in Young Sound and the nearby shelf in August 2009 is among the highest reported from the Arctic (Table 1).

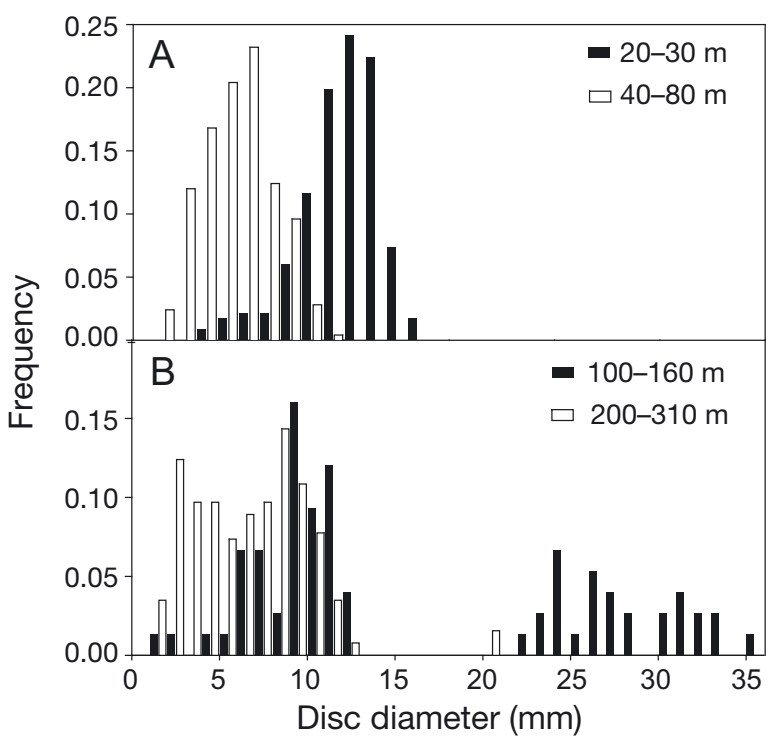

Fig. 2. Size frequency distributions of brittle stars from (A) 20 to $80 \mathrm{~m}$ depth, and (B) 100 to $310 \mathrm{~m}$ depth in Young Sound and the Greenland Sea. All specimens $>20 \mathrm{~mm}$ are Ophiopleura borealis 


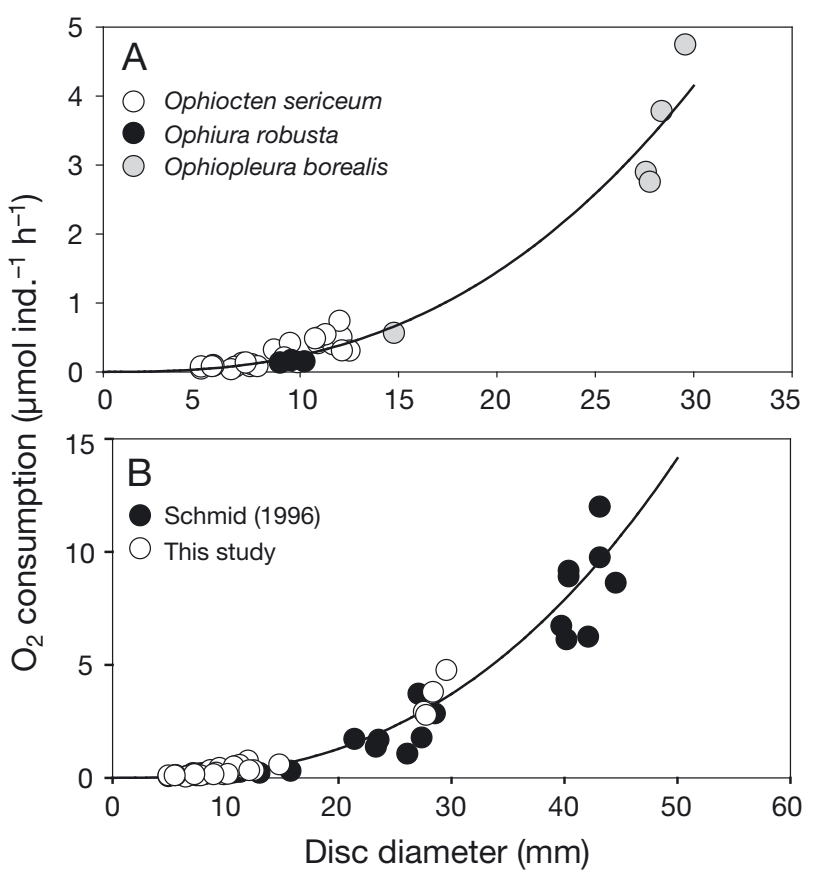

Fig. 3. (A) Average individual oxygen consumption rate, $R\left(\mu \mathrm{mol} \mathrm{O}_{2} \mathrm{~h}^{-1}\right)$, of 3 different species of brittle stars as a function of disc diameter, $D(\mathrm{~mm}): R=0.006 \times D^{2.60}$. (B) General relationship between $D$ and individual $R$ in 6 species of Arctic brittle stars: $R=0.0005 \times D^{2.62}$

Table 1. Estimates of average carbon demand of brittle stars in the Arctic and of other dominant macrobenthic species in Young Sound

\begin{tabular}{|c|c|c|c|}
\hline Species/site & Depth (m) & $\begin{array}{c}\text { Carbon demand } \\
\left(\mathrm{mg} \mathrm{C} \mathrm{m}^{-2} \mathrm{~d}^{-1}\right)\end{array}$ & Reference \\
\hline \multicolumn{4}{|l|}{ Arctic brittle stars } \\
\hline \multirow[t]{3}{*}{ Young Sound } & $20-30$ & 8.5 & This study \\
\hline & $40-80$ & 6.0 & This study \\
\hline & $100-160$ & 9.2 & This study \\
\hline \multicolumn{4}{|l|}{ NE Greenland } \\
\hline Shelf & $200-310$ & 4.5 & This study \\
\hline Banks & $40-150$ & 5.3 & Piepenburg (2000) \\
\hline Trough slopes & $100-580$ & 1.0 & Piepenburg (2000) \\
\hline Trough bottoms & $180-440$ & 0.4 & Piepenburg (2000) \\
\hline Upper slope & $80-770$ & $<0.1$ & Piepenburg (2000) \\
\hline \multirow[t]{2}{*}{ Barents Sea } & $80-100$ & 3.6 & Piepenburg (2000) \\
\hline & $150-360$ & 1.8 & Piepenburg (2000) \\
\hline \multirow[t]{2}{*}{ Laptev Sea } & $14-23$ & 0.1 & Piepenburg (2000) \\
\hline & $30-45$ & 6.2 & Piepenburg (2000) \\
\hline Chukchi Sea & $29-212$ & $6.7^{\mathrm{a}}$ & Ambrose et al. (2001) \\
\hline Beaufort Sea & $32-420$ & 8.8 & Renaud et al. (2007) \\
\hline \multicolumn{4}{|c|}{ Other species in Young Sound } \\
\hline Hiatella arctica & $0-60$ & 2.5 & Sejr et al. (2002) \\
\hline Mya truncata & $10-60$ & 6.8 & Sejr \& Christensen (2007) \\
\hline Strongylocentrotus sp. & $5-65$ & 4.2 & Blicher et al. (2007) \\
\hline
\end{tabular}

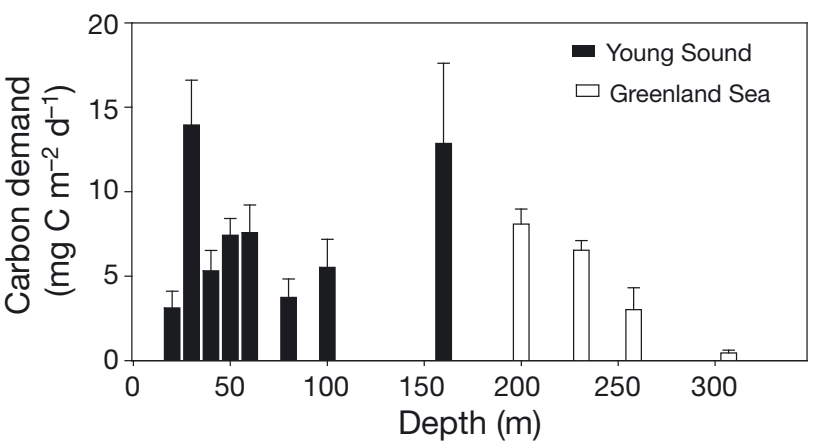

Fig. 4. Average carbon demand $( \pm 95 \% \mathrm{CI})$ of brittle stars, estimated from individual respiration rates, abundance and size frequency distribution

Average carbon demand for the depth intervals studied range from 4.5 to $9.2 \mathrm{mg} \mathrm{C} \mathrm{m}^{-2} \mathrm{~d}^{-1}$. Estimates of total mineralisation in the sediment in summer, as obtained from sediment cores $(5.3 \mathrm{~cm}$ diameter), range from $\sim 30 \mathrm{mg} \mathrm{C} \mathrm{m}^{-2} \mathrm{~d}^{-1}$ (100 to $165 \mathrm{~m}$ depth) to $240 \mathrm{mg} \mathrm{C} \mathrm{m}^{-2}$ $\mathrm{d}^{-1}(20 \mathrm{~m})$ (Glud et al. 2000). Thus, brittle stars contribute an additional 1 to $25 \%$ (average of all stations $=8 \%$ ) to the sediment exchange estimated by Glud et al. (2000), which predominantly included bacterial mineralisation. This is comparable to the contribution from brittle stars in the Barents Sea (depths <200 m, Piepenburg et al. 1995) and the maximum contributions in the Chukchi and Beaufort Seas (Ambrose et al. 2001, Renaud et al. 2007). Besides their direct contribution to ecosystem carbon transport, brittle stars are likely to stimulate bacterial mineralisation by bioturbation (e.g. Vopel et al. 2003) and fractionation of organic material through ingestion and excretion (Mamelona \& Pelletier 2005). Moreover, sub-lethal predation on brittle stars can be significant (Aronson 1992, Sköld \& Rosenberg 1996). Estimates of the annual average carbon demand of 3 other dominant macrobenthic species are available from Young Sound (Table 1). Although their carbon demands are significant, their distribution is limited to shallow depths $(<60 \mathrm{~m})$. In Young Sound, approximately $70 \%$ of the sea floor is found at depths $>60 \mathrm{~m}$ (Bendtsen et al. 2007). When the shelf areas in the Greenland Sea are taken into account, our results demonstrate that brittle stars in NE Greenland are clearly a dominant macrofaunal group in terms of abundance and carbon mineralisation, and an important contributor to marine carbon cycling as such. 
Due to the large standing stock of brittle stars, their carbon demand in Young Sound was relatively high despite low individual respiration rates. The grand average biomass across all depths (600 $\mathrm{mg} \mathrm{C} \mathrm{m}^{-2}$ ) is comparable to maximum values from shelves and slopes in NE Greenland and the Laptev Sea, and exceeds values from the Barents Sea (Piepenburg 2000). However, the maximum biomass of $2190 \mathrm{mg} \mathrm{C}$ $\mathrm{m}^{-2}$ at $160 \mathrm{~m}$ depth is well below the $3388 \mathrm{mg} \mathrm{C} \mathrm{m}^{-2}$ reported from a single station in the Chukchi Sea (Ambrose et al. 2001). The other component used to estimate carbon demand is the average individual respiration rate. To compare our rates with those of Schmid (1996), we converted individual biomasses (ash-free dry weight, AFDW) given in that study to disc diameter using the allometric relationships between disc diameter and body mass (organic C) provided by Piepenburg (2000). The individual respiration rates measured by Schmid (1996) are comparable to our estimates and indicate a general relationship between disc diameter and individual respiration across 6 species of brittle stars encompassing a wide range in size (Fig 3b). It should be noted that values are approximate as they rely on general assumptions regarding the organic C:AFDW ratio and the allometric relationship between biomass and disc diameter to make data directly comparable. Moreover, a general relationship such as this does not consider the potential seasonal variation in macrobenthic activity, which has been reported in other studies in polar areas (Brockington \& Clarke 2001, Blicher et al. 2010). However, it can be used to produce a preliminary estimate of the carbon requirements of this abundant taxon in the Arctic using a more general approach based on size structure and abundance, which can be effectively described using sea-floor images.

Different sediment composition or water mass characteristics are likely to be responsible for the observed patterns in the general abundance of brittle stars as well as the depth zonation of species. Ophiocten sericeum, Ophiura robusta and Ophiopleura borealis are cold-water species mainly occurring in the Arctic (Piepenburg 2000 and references therein). Hence, entrainment of relatively warm Atlantic Water $\left(>2^{\circ} \mathrm{C}\right)$ across the shelf break (Sejr et al. 2009, J. Mortensen unpubl.) might be responsible for the abundance of $O$. bidentata at the deep stations in the Greenland Sea. However, at present our knowledge of the factors controlling the distribution of different species of brittle stars in the Arctic is very limited. Piepenburg (2000) combined data from several Arctic and subArctic regions and found brittle star biomass to peak in the range of 40 to $150 \mathrm{~m}$ with peak abundance at 50 to $100 \mathrm{~m}$, and our data does not deviate from this very general pattern. The dominance of the species
O. sericeum has also been found at depths $<150 \mathrm{~m}$ in NE Greenland at 78 to $81^{\circ} \mathrm{N}$, and in the Barents Sea and the Laptev Sea (Piepenburg 2000).

In summary, the data presented add to existing examples of how macrofauna in general and brittle stars in particular are important components of benthic carbon cycling in Arctic fjords and shelves, potentially adding up to $25 \%$ to the mineralisation of bacteria and meiofauna. Also, the general relationship between disc diameter and individual respiration across 6 species of brittle stars may prove useful to future studies, as it allows a preliminary estimate of brittle star oxygen consumption, mineralisation and carbon demand to be made from sea floor photos.

Acknowledgements. Kunuk Lennert, Thomas Juul-Petersen and Egon Frandsen are thanked for assistance in the field. A. Haxen is thanked for linguistic corrections. The project was funded by the Commission for Scientific Research in Greenland, the Greenland Ecosystem Monitoring program (www.g-em.dk), the Arctic Tipping Points project (www.eu-atp.org) funded by FP7 of the European Union (contract 226248), The Ministry of Culture, Education and Churches (KIIP) and the Aage V. Jensen Charity Foundation.

\section{LITERATURE CITED}

Ambrose WG, Clough LM, Tilney PR, Beer L (2001) Role of echinoderms in benthic remineralisation in the Chukchi Sea. Mar Biol 139:937-949

Aronson RB (1992) Biology of a scale-independent predatorprey interaction. Mar Ecol Prog Ser 89:1-13

Bendtsen J, Gustafsen KE, Rysgaard S, Vang T (2007) Physical conditions, dynamics and model simulations during the ice-free period of the Young Sound/Tyroler Fjord system. In: Rysgaard S, Glud RN (eds) Carbon cycling in Arctic marine ecosystems: case study Young Sound. Bioscience Vol 58, Copenhagen, p 46-59

Blicher ME, Rysgaard S, Sejr MK (2007) Growth and production of sea urchin Strongylocentrotus droebachiensis in a high-Arctic fjord, and growth along a climatic gradient (64 to $77^{\circ} \mathrm{N}$ ). Mar Ecol Prog Ser 341:89-102

Blicher ME, Rysgaard S, Sejr MK (2010) Seasonal growth variation in Chlamys islandica (Bivalvia) from sub-Arctic Greenland is linked to food availability and temperature. Mar Ecol Prog Ser 407:71-86

Brey T, Clarke A (1993) Population dynamics of marine benthic invertebrates in Antarctic and sub-Antarctic environments: Are there unique adaptations? Antarct Sci 5:253-266

Brockington S, Clarke A (2001) The relative influence of temperature and food on the metabolism of a marine invertebrate. J Exp Mar Biol Ecol 258:87-99

Glud RN, Risgaard-Petersen N, Thamdrup B, Fossing $\mathrm{H}$, Rysgaard S (2000) Benthic carbon mineralisation in a high-Arctic sound (Young Sound, NE Greenland). Mar Ecol Prog Ser 206:59-71

> Grebmeier JM, Cooper LW, Feder HM, Sirenko BI (2006) Ecosystem dynamics of the Pacific-influenced Northern Bering and Chukchi Seas in the Amerasian Arctic. Prog Oceanogr 71:331-361

Mahaut ML, Sibuet M, Shirayama Y (1995) Weight-dependent respiration rates in deep-sea organisms. Deep-Sea Res I 42:1575-1582 
Mamelona J, Pelletier É (2005) Green sea urchin as a significant source of fecal particulate organic matter within nearshore benthic ecosystems. J Exp Mar Biol Ecol 314: 163-174

Navarro JM, Thompson RJ (1996) Physiological energetics of the horse mussel Modiolus modiolus in a cold ocean environment. Mar Ecol Prog Ser 138:135-148

Piepenburg D (2000) Arctic brittle stars (Echinodermata: Ophiuroidea). Oceanogr Mar Biol Annu Rev 38:189-256

Piepenburg D, Blackburn $T$, von Dorrien CF, Gutt $\mathrm{J}$ and others (1995) Partitioning of benthic community respiration in the Arctic (northwestern Barents Sea). Mar Ecol Prog Ser 118:199-213

Quiroga E, Sellanes J (2009) Growth and size-structure of Stegophiura sp. (Echinodermata: Ophiuroidea) on the continental slope off central Chile: a comparison between cold seep and non-seep sites. J Mar Biol Assoc UK 89: 421-428

Renaud PE, Morata N, Ambrose WG, Bowie JJ, Chiuchiolo A (2007) Carbon cycling by seafloor communities on the eastern Beaufort Sea shelf. J Exp Mar Biol Ecol 349: 248-260

Schmid MK (1996) On the distribution and oxygen consumption of ecologically important benthic animals in the waters around Svalbard (Arctic). Ber Polarforsch 202: $1-92$

Sejr MK, Christensen PB (2007) Growth, production and carbon demand of macrofauna in Young Sound, with special emphasis on the bivalves Hiatella arctica and Mya truncata In: Rysgaard S, Glud RN (eds) Carbon cycling in Arctic marine ecosystems: case study Young

Editorial responsibility: James McClintock, Birmingham, Alabama, USA
Sound. Bioscience Vol 58, Copenhagen, p 121-135

Sejr MK, Jensen KT, Rysgaard S (2000) Macrozoobenthic community structure in a high-Arctic East Greenland fjord. Polar Biol 23:792-801

Sejr MK, Sand MK, Jensen KT, Petersen JK, Christensen PB, Rysgaard S (2002) Growth and production of Hiatella arctica (Bivalvia) in a high-Arctic fjord (Young Sound, Northeast Greenland). Mar Ecol Prog Ser 244:163-169

Sejr M, Petersen J, Jensen K, Rysgaard S (2004) Effects of food concentration on clearance rate and energy budget of the arctic bivalve Hiatella arctica (L.) at subzero temperature. J Exp Mar Biol Ecol 311:171-183

Sejr MK, Rysgaard S, Mikkelsen D, Hjort M and others (2009) Zackenberg Basic: The MarineBasis programme. In: Jensen LM, Rasch M (eds) Zackenberg Ecological Research Operations, 14th Annual Report, 2008. National Environmental Research Institute, Aarhus University, Denmark, p 66-79

Sköld M, Rosenberg R (1996) Arm regeneration frequency in eight species of ophiuroidea (Echinodermata) from European sea areas. J Sea Res 35:353-362

Smith KL (1983) Metabolism of two dominant epibenthic echinoderms measured at bathyal depths in the Santa Catalina Basin. Mar Biol 72:249-256

Tyler PA (1980) Deep sea ophioriods. Oceanogr Mar Biol Annu Rev 18:125-153

> Vopel K, Thistle D, Rosenberg R (2003) Effect of the brittle star Amphiura filiformis (Amphiuridae, Echinodermata) on oxygen flux into the sediment. Limnol Oceanogr 48: $2034-2045$

Submitted: April 19, 2010; Accepted: November 2, 2010

Proofs received from author(s): January 11, 2011 